Perspective Essay

\title{
Towards an operational methodology to optimize ecosystem services provided by urban soils
}

\author{
Blanchart Anne ${ }^{\mathrm{a}, \mathrm{b}, \mathrm{d}, \mathrm{e}}$, Séré Geoffroy ${ }^{\mathrm{a}, \mathrm{b}}$, Johan Cherel $^{\mathrm{c}}$, Gilles Warot ${ }^{\mathrm{c}}$, Stas Marie ${ }^{\mathrm{a}, \mathrm{b}}$, \\ Consalès Jean Noël ${ }^{\mathrm{d}}$, Morel Jean Louis ${ }^{\mathrm{a}, \mathrm{b}}$, Schwartz Christophe ${ }^{\mathrm{a}, \mathrm{b}, *}$ \\ ${ }^{a}$ Laboratoire Sols et Environnement, Université de Lorraine, UMR 1120, F-54518 Vandoeuvre-lès-Nancy, France \\ ${ }^{\mathrm{b}}$ Laboratoire Sols et Environnement, INRA, UMR 1120, F-54518 Vandouvre-lès-Nancy, France \\ ' SCE Aménagement et Environnement, CS 26220, F-44262 Nantes, France \\ d Aix Marseille Univ, CNRS, TELEMME, MMSH, 13094 Aix-en-Provence Cedex, France \\ e Agence de l'Environnement et de la Maitrise de l'Energie (ADEME), 75015 Paris, France
}

A R T I C L E I N F O

\section{Keywords:}

Urban soil

Soil quality

Ecosystem service

Ecosystem function

Urban planning

Decision support system

\begin{abstract}
A B S T R A C T
Urban soils need to be taken into account by city managers to tackle the major urban environmental issues. As other soils in forest or agricultural environments, urban soils provide a wide range of ecosystem services. However, their contribution remains poorly assessed up to now, and as a result there is a strong lack of consideration by urban planning of the services they provide. Indeed, urban soils are mostly seen as a land surface (land area, two-dimensional system) and if they are characterized, it is almost exclusively for their potential contamination and their geotechnical properties. So, policy makers and planning operators rarely consider soils as a living resource, capable to fulfill essential functions. From the conclusions of previous studies, a selection of ecosystem services provided by soil and adapted to the specificity of urban context is proposed. This paper also aims at proposing the concept of the DESTISOL decision support system for urban planning projects upstream of the planning decisions, illustrated by an application example. It is based on an integrative approach linking soil quality indicators (e.g. physico-chemical and biological characteristics, fertility, pollution), soil functions and soil ecosystem services. The method leads to the semi-quantitative assessment of the level of ecosystem services that are either provided by urban soils or required to fit with the urban design.
\end{abstract}

\section{Introduction}

Urban soils are an insufficiently recognized resource for the conception and construction of sustainable cities. Urban areas, in addition to global environmental issues, concentrate major local environmental concerns such as food-sufficiency, flood mitigation and urban heat island (Craul, 1992; Jenerette, Harlan, Stefanov, \& Martin, 2011). To tackle those issues, every land surface - including cities - should be considered as a potential supplier of ecosystem services (GómezBaggethun \& Barton, 2013). Ecosystem services are defined as the benefits human populations obtain, directly or indirectly, from the ecosystem (e.g. climate regulation, food production, energy supply) (Costanza et al., 1997; MEA, 2005). However, because of their high level of anthropization, urban soils are complex ecosystems that are poorly studied for their contribution to ecosystem services. So far, studies dealing with ecosystem services have focused mainly on natural (forest and aquatic habitat) or moderately anthropized (agricultural) environments (InVEST, 2015; UFORE, 2009). Indeed, the transposition of the concept of ecosystem services to urban environments is recent (Bolund \& Hunhammar, 1999; TEEB, 2011) and mainly sectored. The research conducted so far refers to specific aspects, such as carbon storage in cities and global climate regulation (Davies, Edmondson, Heinemeyer, Leake, \& Gaston, 2011; Herrmann, Shuster, \& Garmestani, 2017; Jim \& Chen, 2009; Lorenz \& Lal, 2009; Pouyat, Groffman, Yesilonis, \& Hernandez, 2002; Pouyat, Yesiloni, \& Golubiewski, 2009; Pouyat, Yesilonis, \& Nowak, 2006; Schmitt-Harsh, Mincey, Patterson, Fischer, \& Evans, 2013), regulation of the urban heat island (Cameron et al., 2012; Jenerette et al., 2011; Lehmann, Mathey, Rossler, Brauer, \& Goldberg, 2014; Norman et al., 2012), and green infrastructures (Cameron et al., 2012; Clergeau, 2012; Jim, 1998; Oberndorfer et al., 2007; Rhea, Shuster, Shaffer, \& Losco, 2014).

Such a lack of knowledge leads to less consideration of urban soils by city managers and urban planners. Urban planning is defined as a technical and political process dealing with the organization of land

\footnotetext{
* Corresponding author at: Laboratoire Sols et Environnement, 2, avenue de la forêt de Haye - BP 20163, 54505 Vandoeuvre-lès-Nancy Cedex, France.

E-mail addresses: anne.blanchart@univ-lorraine.fr (B. Anne), geoffroy.sere@univ-lorraine.fr (S. Geoffroy), johan.cherel@sce.fr (J. Cherel), gilles.warot@sce.fr (G. Warot), jean-louis.moral@univ-lorraine.fr (M.J. Louis), christophe.schwartz@univ-lorraine.fr (S. Christophe).
} 
use, the design of the urban environment, the welfare of people and the protection of the natural environment (Taylor, 2007). In urban planning, urban soils are mainly considered two-dimensionally by urban planners, as a surface area characterized by its land uses, where buildings and infrastructures can be built. The volume of urban soils is characterized only for geotechnical properties or contamination levels. Urban planners do not consider urban soils as a potential living, fertile and tri-dimensional compartment of the urban ecosystem able to perform highly diversified functions and provide ecosystem services (Morel, Chenu, \& Lorenz, 2014).

Soil functions are the product of their physical, chemical and biological characteristics (Natural Capital), and the processes they generate (Schindelbeck et al., 2008). Soil quality refers to the capacity of a soil to function within a given ecosystem and land use boundaries, to sustain productivity, maintain environmental quality and promote plant and animal health (Doran \& Parkin, 1994; Vrščaj, Poggio, \& Marsan, 2008). Taking into account urban soil quality into urban planning strategy would contribute to the mitigation of the major environmental issues and to the development of sustainable and resilient cities by optimizing ecosystem services. This goal requires a reconsideration of the management of urban areas, and the development of a full chain of knowledge, techniques and tools. Hence, cooperation should be promoted between soil scientists and urban planners. As a result, to develop sustainable management of urban areas, it is of utmost importance to build decision support systems (DSS) that take into account ecosystem services provided by soils. The concept of ecosystem service, with its advantage of being understood and shared by the various actors of urban development (e.g. policy makers, operators, urban planners), shall be the cornerstone of such a DSS.

Therefore, this paper was aimed at i) emphasizing the original features of soils in the urban ecosystem, ii) proposing, from the most recent knowledge, a contextualized list of ecosystem services provided by urban soils, iii) analyzing existing urban soil quality assessment tools to formulate propositions for an operational approach, and (iv) proposing and giving an example of application of a new type of DSS based on an integrative approach, linking soil indicators, soil functions and soil ecosystem services, in order to improve urban planning.

\section{Urban soils as by-products of human activities and key components of urban ecosystems}

"Urban soil constitutes the archaeological deposit between the present surface and the natural roof levels and is located in the historic city center" (Fondrillon, 2007). Such an archaeological definition describes the urban soil only by its historical formation and its location in the territory. It should be completed by the World Reference Base for Soil Resources (WRB), which defines the soil as "any material within two meters of the Earth's surface that is in contact with the atmosphere, excluding living organisms, areas with continuous ice not covered by other material, and water bodies deeper than two meters" (IUSS Working Group WRB, 2015). In the present paper, we used the term urban soils to refer to "soils that are under strong human influence in the urban and suburban landscape" (de Kimpe \& Morel, 2000), whether in presence or absence of vegetation. Also, "urban soil" may stand for all soils under human influence that can be found not only in urban areas, but also in a wider range of locations (e.g. soils from an industrial brownfield are considered as urban soils in this paper). In this case, urban soil is synonym of SUITMA (Soils of Urban, Industrial, Traffic, Mining and Military Areas) (Morel et al., 2014).

At the urban area scale, human influence leads to a great variety of soils on a limited surface area (compared to natural environments) and to a lack of spatial logic (Effland \& Pouyat, 1997; Morel \& Schwartz, 1999). It should be noted that deeply degraded soils, strongly transformed soils and pseudo-natural soils showing only little changes, may coexist in urban areas (Morel et al., 2014). This high variability could be explained by the fact that urban soils are characterized by a wide range of various activities over time (Norra \& Stuben, 2003) and by a very frequent change of use. More precisely, urban soils may result in the combination, in various proportions, of exogenous materials - either anthropogenic (so called technic materials), geologic or soil materials - and of native soils. At the pedon scale, they present a strong vertical and horizontal spatial heterogeneity of their physical, chemical and biological properties (Béchet et al., 2009; Craul, 1992; Morel, Schwartz, \& Florentin, 2005; Schwartz, 2001). Urban soils are associated with a large range of features, among them coarse texture, high bulk density, alkaline $\mathrm{pH}$ are specific to urban soils (Burghardt, Morel, \& Zhang, 2015; Joimel et al., 2016; Kida \& Kawahigashi, 2015; Leguédois et al., 2016; Pouyat et al., 2007; Shaw, 2015). Furthermore, the incorporation of artefacts as well as residues from human activities (e.g. traffic, industry) may cause contamination (Béchet et al., 2009; Craul, 1992; El Khalil et al., 2013; Joimel et al., 2016) in the coarse fraction and fine earth (El Khalil et al., 2008). As a consequence, the physical and chemical fertility of urban soils is often low, even if some of them are designed to provide a suitable medium for plant growth and biomass production (e.g. in green areas, gardens, green roofs, constructed soils) (Joimel et al., 2016; Morel \& Schwartz, 1999; Rokia et al., 2014; Séré et al., 2008). Despite all their original characteristics, soils in urban ecosystems are capable of providing ecosystem services in a similar way as agricultural or forest soils.

\section{Ecosystem services provided by urban soils to face major urban environmental issues}

Urban areas are confronted by specific, major environmental issues (e.g. food dependency, local climate), as they concentrate population, activities and infrastructures. Ecosystem services provided by urban environments are rarely linked with soils. However, urban soils and their associated ecosystem services are crucial for the management of most of those environmental problems. For natural environments, the functional capacity of soils is used in an interdisciplinary framework to assess ecosystem services and "to focus on exploring soil functional diversity of soil biota and the spatial aspects of soil properties to lower level ecosystem services" (e.g. Adhikari \& Hartemink, 2015; Dominati, Patterson, \& Mackay, 2010; Morel and Heinrich, 2008). Despite an increasing number of papers dealing with "ecosystem services" and "urban soils" (7 papers in 2005 and 50 in 2015), the ratio of the number of papers citing "ecosystem services" + "urban" + "soil" on the number of papers mentioning only "ecosystem services" has remained stable. Recently, a semi-quantitative evaluation of four categories of SUITMAs: sealed soils, landfill soils, pseudo-natural vegetated soils and constructed vegetated soils was proposed (Morel et al., 2014). In urban areas, whatever the degree of anthropization of soils, they all can provide services in order to sustain and fulfill human life. As an example, vegetated pseudo-natural soils ensure better habitats for biodiversity than dumping sites, or in extreme cases, than sealed soils. In the same extent, sealed soils ensure the transportation of goods, energy, and human beings, unlike vegetated constructed soils. As a result, compromises have to be made, as a given soil cannot provide the whole range of services.

Following the propositions of many authors (e.g. Escobedo, Kroeger, \& Wagner, 2011) and adapting the existing lists (Costanza et al., 1997; de Groot, Wilson, \& Boumans, 2002; MEA, 2003) to the urban context, we have established an integrated list of ecosystem services provided by soils in the urban environment (Table 1). Considering the international agreement on the status of "supporting services" (Dominati, 2013), and the idea that the quantification of ecosystem services needs to focus only on benefits directly useful to humans, it appears more relevant in the urban context to express this concept as a "soil's capital" (Fischer, Kerry Turner, \& Morling, 2009). Indeed, as previously mentioned, urban soils are singular in the association of natural and technical components, as some of them were implemented on purpose to enhance their functions (e.g. pipes, underground structure, bitumen). So, 
Table 1

List of seventeen targeted ecosystem services provided by urban soils.

\begin{tabular}{|c|c|c|}
\hline & Indicators & $\begin{array}{l}\text { Assessment tool for soil } \\
\text { quality }\end{array}$ \\
\hline \multirow[t]{17}{*}{ Regulating } & \multirow[t]{4}{*}{ Air quality regulation } & $\mathrm{CO}_{2}$ \\
\hline & & $\mathrm{O}_{3}$ \\
\hline & & Fine particles \\
\hline & & Acid rain \\
\hline & \multirow[t]{3}{*}{ Climate regulation } & Local climate \\
\hline & & Global climate \\
\hline & & Indoor climate \\
\hline & \multirow[t]{2}{*}{ Waste treatment } & Storage \\
\hline & & Recycling \\
\hline & \multirow[t]{2}{*}{ Water purification } & Pollutant sequestration \\
\hline & & Pollutant degradation \\
\hline & Noise attenuation & - \\
\hline & \multirow[t]{5}{*}{ Natural hazard mitigation } & Strom \\
\hline & & Flood \\
\hline & & Earthquakes \\
\hline & & Erosion \\
\hline & & Disease regulation \\
\hline \multirow[t]{28}{*}{ Provisioning } & \multirow[t]{4}{*}{ Food } & Cereals and vegetables \\
\hline & & Fruits \\
\hline & & Meat \\
\hline & & Mushroom \\
\hline & \multirow{2}{*}{$\begin{array}{l}\text { Support for human activities \& } \\
\text { services }\end{array}$} & Health \& education facilities \\
\hline & & $\begin{array}{l}\text { Commercial \& industrial } \\
\text { facilities }\end{array}$ \\
\hline & \multirow[t]{3}{*}{ Support for human infrastructures } & Roads \& utility services \\
\hline & & Public areas \\
\hline & & Building \\
\hline & \multirow[t]{2}{*}{ Support for animals habitat } & Genetic resources \\
\hline & & Biodiversity \\
\hline & \multirow[t]{3}{*}{ Fiber \& raw materials } & Mineral raw material \\
\hline & & Fibers (wood, textile, ...) \\
\hline & & Fuel \\
\hline & \multirow[t]{5}{*}{ Energy } & Solar \\
\hline & & Wind \\
\hline & & Biomass \\
\hline & & Deep geothermal energy \\
\hline & & Surface geothermal energy \\
\hline & \multirow{2}{*}{$\begin{array}{l}\text { Biochemical products \& medicinal } \\
\text { resources }\end{array}$} & Other \\
\hline & & Medicinal plants \\
\hline & \multirow[t]{4}{*}{ Ornemental resources } & Grass \\
\hline & & Shrubs \\
\hline & & Trees \\
\hline & & Flowers \\
\hline & \multirow[t]{3}{*}{ Transportation of fluids } & Drinking water \\
\hline & & Sewage water \\
\hline & & Energy \& telecommunication \\
\hline \multirow[t]{5}{*}{ Cultural } & Heritage conservation & History \& archeology \\
\hline & \multirow[t]{4}{*}{ Leisure } & Recreational activities \\
\hline & & Landscape-features \& aesthetic \\
\hline & & Tourism \\
\hline & & Spiritual \& religious inspiration \\
\hline
\end{tabular}

services provided by urban soils are naturally occurring anthropogenic benefits. As a consequence, we will consider the "Natural and Artificial Capital" of urban soils (Robinson, 2014) in addition to the list of ecosystem services. We base our list on three of the four categories defined in the TEEB (e.g. regulation services, provisioning services and cultural services) (TEEB, 2011). Adapting the list to the urban context leads to opening the "provisioning services" category to services such as "support for human services and activities", "support for human infrastructure", "transportation of fluids" or "ornamental resources", which are essential issues in urban planning (Table 1).

The list of ecosystem services provided by urban soils highlights their potential contribution to solving the main environmental issues faced by urban ecosystems (Fig. 1). Such an explicit representation should draw the attention of urban planners and managers to the benefits to be gained through an improved integration of soil quality in the construction and functioning of a sustainable urban environment.

\section{Evaluation of soil quality for its management in urban planning: the existing DSS}

Ecosystem services provided by urban soils depend on soil quality (Hepperle \& Schulin, 2008; Ossola \& Livesley, 2016). Generally, soil quality is assessed using several indicators (e.g. soil texture, $\mathrm{pH}$, organic matter content, available nutrients) that are aggregated into main indexes (e.g. structural stability, chemical fertility) (Andrews, Karlen, \& Cambardella, 2004; Vrščaj et al., 2008). The assessment of soil quality is frequently based on a rating system that weights indicator values (Schindelbeck et al., 2008; Velasquez, Lavelle, \& Andrade, 2007; Vrščaj et al., 2008). Among the existing tools usually developed at the international level for soils, three distinct approaches have been specifically proposed for the urban context. These most cited projects have been developed in the European context:

i) the European "Urban SMS" tool (http://www.urban-sms.eu) was developed from the method developed by Vrščaj et al. (2008) (URBAN, 2008) in order to enhance the consideration of urban soils functions in the planning process. It is based on a multi-criteria analysis and estimates the ability of soils to fulfill varying land uses;

ii) the UQualiSol-ZU project (GESSOL, 2012) aims at guiding the use of natural soils in urban projects. This tool estimates the multi-functionality of soils in order to preserve the most multifunctional soils during land use changes. The ultimate aim is to integrate soil quality indices in urban planning documents;

iii) the European "ENVASSO" project (http://esdac.jrc.ec.europa.eu/ projects/envasso, ENVASSO, 2006) is rather different from the first two approaches. It proposes a basis for building a soil monitoring system at the continental level. Various indicators have been selected for their ability to indirectly assess soil functions, in relation to the threats that may affect soils (e.g. erosion, loss of organic matter, contamination, compaction, biodiversity loss, sealing and flooding).

Soil indicators proposed by the three approaches are given Table 2 . We have sorted them into "general soil properties", "chemical indicators", biological indicators", "physical indicators" and "contamination indicators". Some indicators are obtained from direct measurement (e.g. slope, electrical conductivity, bacterial diversity, clay content, trace elements/contaminants content), some are derived from models (e.g. water storage capacity, soil erodibility), and while others are interpreted observations (e.g. soil surface state, biogenic structure). The described approaches proposed ranking systems for all indicators depending on either land use (Urban SMS) or soil functions (UQualiSol-ZU). Each indicator's numerical value or observation is converted into a score.

Despite their relevance to addressing soil quality issues, these European approaches exhibit limitations. A first limit is that most indicators are applied to the topsoil alone. Also, indicators of the Urban SMS tool are difficult to implement and to transpose to other cities because: (i) their acquisition requires complex procedures, and (ii) they may be hardly understood by city planners (Neel, Delcour, \& Dumont, 2012). Furthermore, assessment of some soil properties is not an easy task with unique and independent indicators. For example, biological parameters, such as microbial biomass, and chemical indicators such as soil organic matter, exchangeable nitrogen and phosphorus, or cation exchange capacity are equally important in describing the mineralization of organic matter (Williams \& Hedlund, 2014).

On the basis of these findings developed in European countries, we formulate some propositions in order to facilitate the consideration of soil quality in urban management choices, and applicable at a global scale: 


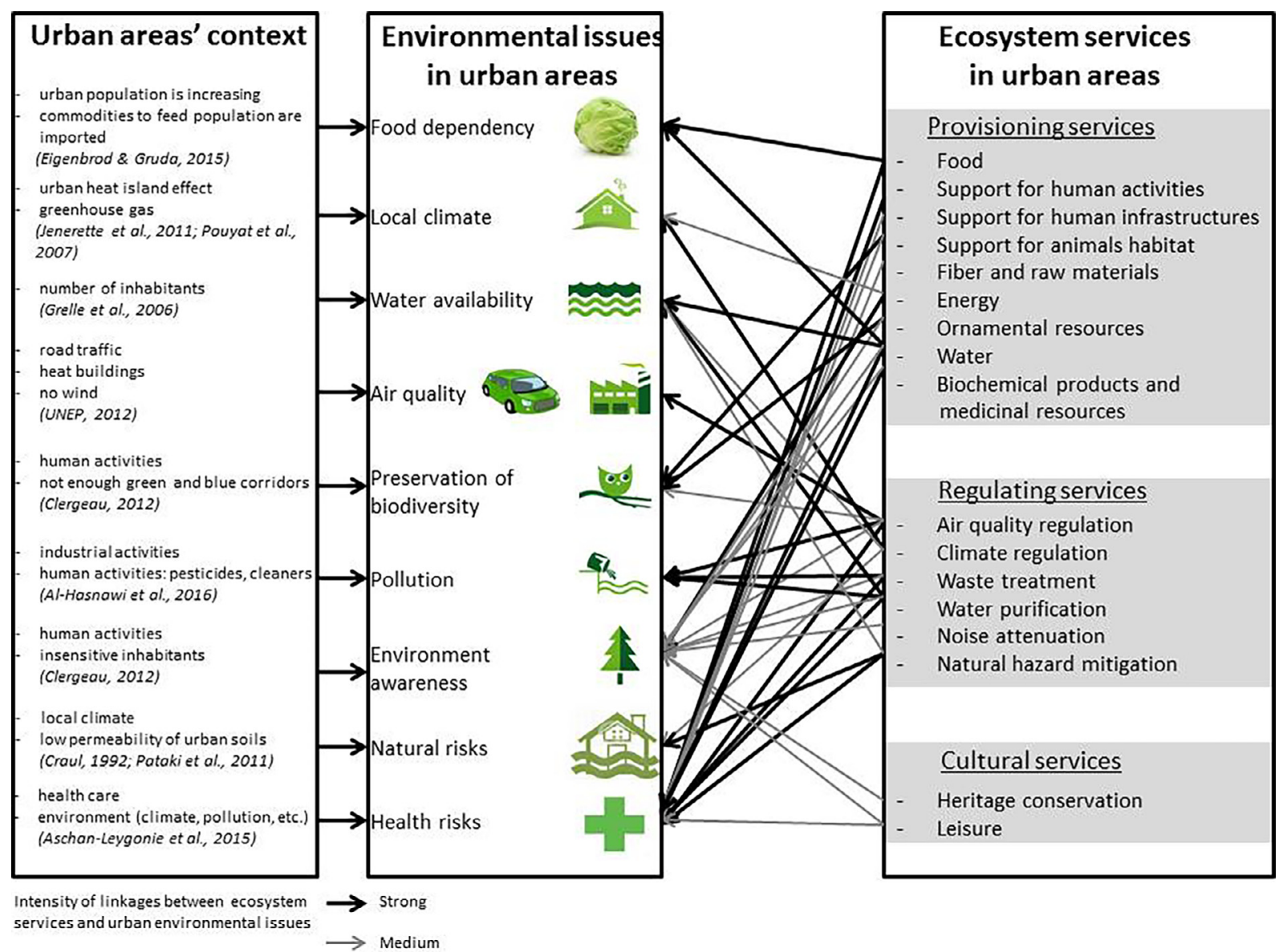

Fig. 1. Links between seventeen targeted ecosystem services provided by urban soils and major environmental issues in urban areas.

1. First, and at least during the first stages of the development of an urban soil quality assessment tool, only a restricted number of indicators shall be considered. Their selection relies on their ease of implementation and ease of understanding by the actors of urban planning. Their selection also depends on the urban context in which the project plot falls (e.g. urban renewal, EcoQuartier) and on the main expectations of the future urban project (e.g. increasing of housing supply, enhancing the comfort of town folks);

2. Secondly, the use of indicators that rely on a descriptive integrative approach and that express the functioning of soil should be promoted by revisiting former concepts such as "cultural profile" (Hénin, Féodoroff, Gras, \& Monnier, 1960). In addition, to integrate the vertical and horizontal heterogeneities of urban soils, we propose to rest the quality assessment upon an adequate number of large pedological pits per plot (minimum volume: $1 \mathrm{~m}$ deep, $1 \mathrm{~m}$ large and $1.5 \mathrm{~m}$ long) instead of an exclusive use of punctual soil surveys;

3. Finally, adequate ranking systems are required for each indicator. Indeed, the scoring system needs to integrate not only the original features of the urban soils, but also the specificity of urban land uses (e.g. green roof, urban square, buildings).

The simplicity and robustness of the urban soil quality assessment approach appears to be an absolute prerequisite to its integration in an operational methodology for urban planners. Later, after its appropriation, such a tool could be improved to integrate a greater complexity.
5. Main guiding principles for the development of an operational DSS to optimize ecosystem services provided by urban soils

The optimization of ecosystem services provided by urban soils requires the integration of urban soil quality into urban planning (Gaston, Avila-Jimenez, \& Edmondson, 2013; Niemelä et al., 2010). To reach such a goal, we suggest the following:

1. As discussed above, DSS are relevant tools for urban planning as they contribute to matching land use with soil quality (Andrews et al., 2004; Keller \& Robert, 2012). However, since DSS aims at taking into account soil quality in urban development projects, it must be co-constructed by the actors involved in both the knowledge and management of soils (i.e. soil scientists and urban planners). Indeed, these actors, who do not usually work together, have the opportunity to exchange ideas and to develop a common vocabulary. By comparing distinct viewpoints on a similar object (i.e. urban soil) a co-construction will reduce costs and save time, and surely improve urban planning projects.

2. Soil is the main compartment of terrestrial ecosystems. As an operational method, DSS takes into account those interactions that occur within the ecosystem and express the potential ecosystem services that can be provided by urban soils. The structure of the DSS requires the implementation of a succession of internal models and databases that link relevant soil indicators to soil functions, then to ecosystem functions and finally to ecosystem services as described by Dominati (2013) and Adhikari and Hartemink (2015). For example, to evaluate the capacity of a soil to mitigate local climate (ecosystem service) (Fig. 2), it is necessary to evaluate the water infiltration capacity, the organic matter recycling capacity, the growth and 
Table 2

Inventory of soil indicators used in existing assessment tool for soil quality.

\begin{tabular}{|c|c|c|}
\hline & Indicators & $\begin{array}{l}\text { Assessment tool for soil } \\
\text { quality }\end{array}$ \\
\hline \multirow[t]{4}{*}{ Global soil properties } & Soil depth & Urban SMS, UqualiSol-ZU \\
\hline & Slope & Urban SMS, UqualiSol-ZU \\
\hline & Sealed surface & ENVASSO \\
\hline & Soil surface state & UqualiSol-ZU \\
\hline \multirow[t]{13}{*}{ Physical indicators } & Texture class & Urban SMS, UqualiSol-ZU \\
\hline & Clay content & Urban SMS, UqualiSol-ZU \\
\hline & Sand content & Urban SMS, UqualiSol-ZU \\
\hline & Bulk density & ENVASSO \\
\hline & Total porosity & ENVASSO \\
\hline & Water storage capacity & UqualiSol-ZU \\
\hline & $\begin{array}{l}\text { Saturated hydraulic } \\
\text { conductivity }\end{array}$ & Urban SMS, UqualiSol-ZU \\
\hline & Hydromorphy & UqualiSol-ZU \\
\hline & Soil erodibility & UqualiSol-ZU, ENVASSO \\
\hline & Mechanical resistance & UqualiSol-ZU, ENVASSO \\
\hline & Magnetic susceptibility & UqualiSol-ZU \\
\hline & Air capacity & ENVASSO \\
\hline & Drainage condition & ENVASSO \\
\hline \multirow[t]{10}{*}{ Chemical indicators } & Organic matter & $\begin{array}{l}\text { Urban SMS, UqualiSol- } \\
Z U, \text { ENVASSO }\end{array}$ \\
\hline & Total nitrogen content & Urban SMS, UqualiSol-ZU \\
\hline & $\mathrm{C}: \mathrm{N}$ ratio & ENVASSO \\
\hline & Total phosphorus content & UqualiSol-ZU \\
\hline & $\begin{array}{l}\text { Exchangeable phosphorus } \\
\text { content }\end{array}$ & Urban SMS \\
\hline & $\begin{array}{l}\text { Exchangeable potassium } \\
\text { content }\end{array}$ & Urban SMS \\
\hline & $\mathrm{pH}$ & $\begin{array}{l}\text { Urban SMS, UqualiSol- } \\
Z U, \text { ENVASSO }\end{array}$ \\
\hline & Cation exchange capacity & UqualiSol-ZU \\
\hline & Total $\mathrm{CaCO}_{3}$ content & UqualiSol-ZU \\
\hline & Electrical conductivity & UqualiSol-ZU \\
\hline \multirow[t]{8}{*}{ Biological indicators } & Bacterial diversity & UqualiSol-ZU, ENVASSO \\
\hline & Macro fauna diversity & ENVASSO \\
\hline & Meso fauna diversity & ENVASSO \\
\hline & $\begin{array}{l}\text { Micro fauna \& microflora } \\
\text { diversity }\end{array}$ & ENVASSO \\
\hline & Soil respiration & UqualiSol-ZU, ENVASSO \\
\hline & Biogenic structures & ENVASSO \\
\hline & Enzymatic activities & UqualiSol-ZU, ENVASSO \\
\hline & $\begin{array}{l}\text { Organic matter } \\
\text { degradation amount }\end{array}$ & ENVASSO \\
\hline \multirow[t]{2}{*}{$\begin{array}{c}\text { Contamination } \\
\text { indicators }\end{array}$} & Trace elements content & $\begin{array}{l}\text { Urban SMS, UqualiSol- } \\
Z U, \text { ENVASSO }\end{array}$ \\
\hline & $\begin{array}{l}\text { Persistent organic } \\
\text { pollutants content }\end{array}$ & UqualiSol-ZU, ENVASSO \\
\hline
\end{tabular}

development of trees capacity and the capacity to support biodiversity (soil functions), which are strongly linked to the evaluation of many indicators, such as the soil texture, the soil structure or the biological activity (soil indicators). Furthermore, land cover is of primary importance for at least two reasons. On the one hand, land cover is dependent on intrinsic soil quality and soil functions. A building (one type of soil cover) could not be installed on a soil with poor geotechnical properties; a garden (another type of soil cover) is unreasonable on a heavily contaminated soil or irrelevant on a soil with low fertility. On the other hand, land cover strongly influences soil functions and ecosystem functions. For example, water infiltration is very different under lawn than under traffic areas whatever the intrinsic soil properties.

3. In the construction of a DSS, economic aspects should not be neglected. For most authors (Costanza et al., 1997; Daily, 1997), the monetization of ecosystem services (MES) is a relevant way to make Nature visible to decision makers and financial markets (Baveye, Baveye, \& Gowdy, 2013). According to Liu et al. (2010), economists have long worked on the development of various methods to monetize and apply values to each ecosystem service. In parallel, many international organizations have drawn up policies based on MES. However, such works were abundantly discussed. Cost-benefit analyses applied to environmental goods and services were described as the "commensuration of the incommensurable" (Ghiselin, 1997). Accordingly, cost-benefit analysis method would be based on an unreal and impossible method. "Instead of assessing costs and benefits on the same basis, it ignores costs and benefits that cannot be monetized at all" (Georgescu-Roegen, 1977). Taking into account the specific nature of the implementation of urban projects, economic aspects could be easily integrated. Indeed, public and landscaping works are always required during the operational phases of urban planning. Soil treatments (e.g. soil compaction, liming, decontamination) and backfilling (e.g. fertile topsoil, granulates) are usual procedures that can be monetized. Such a DSS tool will contribute to optimize the land uses as a function of soil quality. The potential cost reduction could therefore be calculated. In addition, the assessment of all the ecosystem services that would be provided by soils - including unexpected ones such as global climate regulation through carbon storage - will highlight the benefits for the urban planners.

\section{Towards the DESTISOL DSS}

\subsection{Presentation of the DESTISOL DSS}

Integrating all these recommendations, we propose a new DSS dedicated to the redevelopment of urban brownfields by the semiquantitative evaluation of ecosystem services at the scale of a site (i.e. from about 1 to 20 ha). This tool, called DESTISOL, is developed within the framework of the research project of the same name, funded by the French environmental agency (ADEME). It is based on an integrative approach, linking soil indicators, soil functions, land covers and soil ecosystem services provided by the various soils of a project site. It is made of a succession of steps that requires different modules, based on ranking systems that were described in the previous sections (Fig. 2):

1. The first step of the DESTISOL DSS aims at acquiring representative data about soil indicators. It requires the definition of homogeneous zones on the site. Such an approach is conducted by combining the collection of data (e.g. pedology, geology, hydrogeology, hydrology, topography, past land uses, contamination diagnosis, current land covers) and field investigation to describe variability of soils. A preliminary visit of the project site allows carrying out surveys with an auger in order to validate or modify the homogeneous zones defined preliminarily by the documentary investigations. After determining the homogeneous zones considering all the data available and the field observations, several soil pits (at least 3) need to be dug on each zone. In this way, there are 3 soil pits per homogeneous zones, such as 3 replicates. Indeed, the approach requires the description of the vertical and horizontal heterogeneities of the pedons. Each soil horizon is described using a selection of soil indicators derived from morphological observations carried out in situ. In addition, every horizon is sampled to perform several analyses at the laboratory in order to acquire complementary soil indicators (e.g. physico-chemical and geotechnical properties, contaminant concentrations). In accordance with the guiding principles, a restricted number of indicators is selected that are easily assessable and understandable by urban planners and policy makers (e.g. soil structure, $\mathrm{pH}$, organic matter). The output is a list of data for all soil indicators for all the homogeneous zones of the site (Table 2).

2. The second step is the integration of the data in the first module of the DSS that aims at scoring soil functions. It converts every value of every soil indicator - that can be either numerical or descriptive into a score, and then uses relevant soil indicators scores to evaluate every soil functions. These results can be interpreted in terms of soil quality evaluation, considering the different scores of the soil 


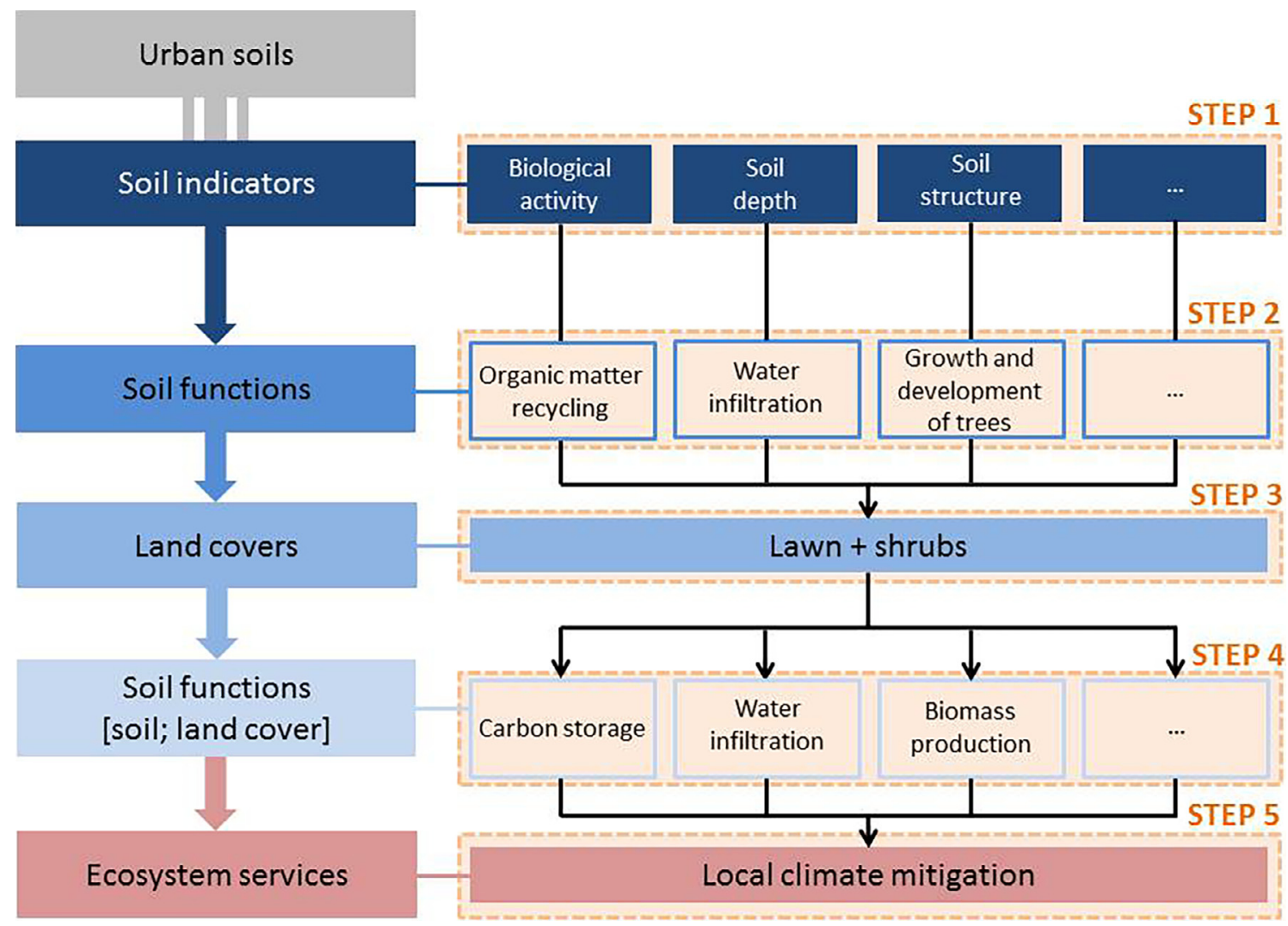

Fig. 2. The steps for a semi-quantitative evaluation of ecosystem services provided by urban soils - the DESTISOL decision support system.

functions for every zone.

3. The third step is the determination of the potential soil covers that are compatible with the scores of the soil functions. These are the covers that the soil can withstand without any anthropogenic modification of its intrinsic characteristics. For example, if a fertile but very shallow soil has been identified on a specific zone of the site, it would have a high score on such soil functions as "organic matter recycling" and "habitat for biodiversity", but an average for "water infiltration" and a bad one for "growth and development of trees". Therefore, a land cover such as "lawn with shrubs" is possible, whereas "tree" is impossible. Similar approaches are applied for the evaluation of all the soil covers, including "building" and "paved soil", that are either possible or not on every zone of the site. From this step, only the possible soil covers are considered for the following steps.

4. The fourth step simply aims at recalculating the scores of all the soil functions for all the possible soil covers. Indeed, as previously explained, soil covers may lower, not modify or increase the scores of the soil functions determined from the second step. As suggested before, a "traffic area" land cover would decrease the score for such soil functions as "water infiltration" and "biomass production", but would increase "protection against erosion". In other words, this step evaluates the soil functions fulfilled by each pair [soil; cover].

5. Then, the last step aims at giving a semi-quantitative evaluation, i.e. scores, of the soil ecosystem services that the soils from all the homogeneous zones of the site can provide. This is calculated from a selection of relevant soil functions scores for every soil ecosystem services. The latter are weighted according to their relevance to each ecosystem service. For example, the "local climate regulation service" would rely mainly on the soil function "carbon storage", but also, to a lesser extent, on "protection against erosion" and "biomass production". But the land cover would also influence this ecosystem service, as it would be improved in the case of the presence of vegetation (either "lawn" or "tree") and would remain constant over time under a "paved soil".

\subsection{How to use the DESTISOL tool}

Our example considers a site to be developed which would currently be an urban brownfield (Fig. 3). An existing urban development plan ("Project A") has been developed by urban planners. The first stage of the procedure begins with documentary review of all the existing data on the site and its environment, followed by a visit of the site which allows carrying out surveys with an auger. This leads to a zoning of the site, each zone being assumed to be homogeneous considering the soil ("Zone 1", "Zone 2", "Zone 3"). The second stage is the realization of an in situ diagnostic of the soil quality by digging several pits on each zone, by describing all soil profiles, by sampling every layers/horizons that are observed and by measuring their geotechnico-physico-chemical properties and their concentrations in contaminants. These observations lead to a revision of the initial zoning by considering heterogeneity in the soils properties. The third stage is the operation of the tool, with all the steps that were described in the previous section. As a result, the DESTISOL tool provides information about the soil covers that are compatible with the various soils of the site in its actual state (e.g. "on Zone 1, considering the soil quality, only roadway and lawn are possible whereas all the existing soil covers are possible on Zone 3") (Fig. 3). Then, two options are available:

- The first one is to compare the soil covers of "project A" with the potential soil covers. In case of incompatibility, the DESTISOL DSS provides objective values to reach for each indicator. Earthwork (e.g. input of arable topsoil), pedological engineering (e.g. soil construction) (Séré et al., 2008) or geotechnical (e.g. liming) approaches could therefore be conducted to improve the existing soils in order to ensure the compatibility with the soil covers of "Project A". Of course, such operations would request additional costs and engineering. 


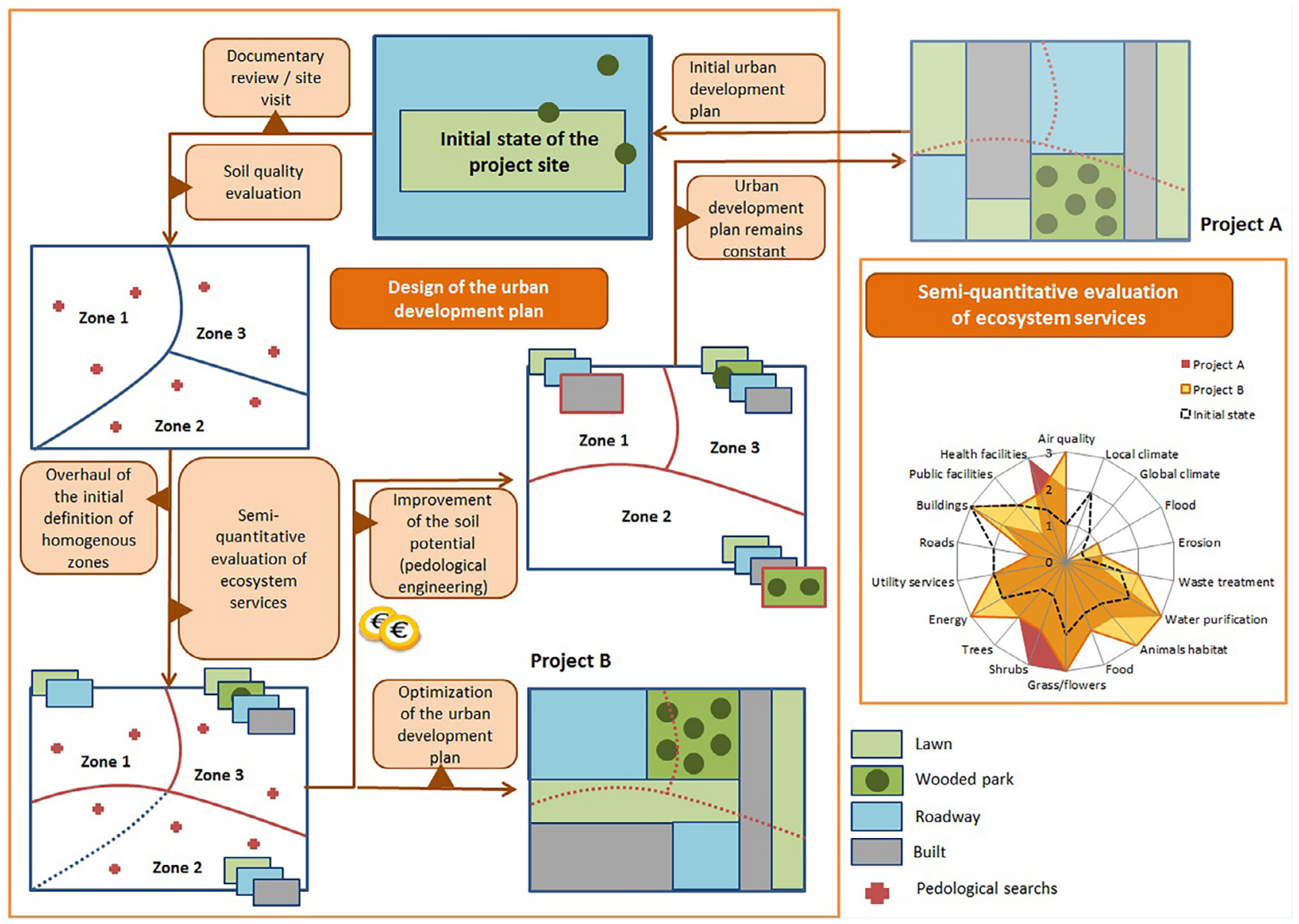

Fig. 3. An example of an application of the DESTISOL decision support system at the scale of an urban development project - how to consider soil quality to optimize ecosystem services provided by urban soils.

- The alternative is to develop "Project B" by revising "Project A". The different units of the urban development plan (with equal surfaces) are moved in order to optimize the soil covers with the actual qualities of the different soils. For example, gardens and green areas would be preferentially located on fertile soils, buildings would be located on less fertile soils and traffic areas and parking lots might be considered on moderately contaminated areas.

The final stage is the semi-quantification of the ecosystem services that could be performed for both the initial site, "Project A" and "Project B". In order to face some major local environmental stakes, some ecosystem services such as "flood mitigation" or "local climate regulation" can be targeted. Thus, we believe that expressing the DSS and its repercussions in an understandable and very practical and effective manner could significantly contribute to the awareness of both urban planners and politicians on how urban soils are useful.

\section{Conclusion and perspectives}

As well as other ecosystems, the urban environment provides a large diversity of services. We have discussed that urban soils, as a natural and artificial capital, are a main contributor to fundamental ecosystem services (e.g. food production, air quality, flood mitigation, climate regulation). Hence they are an essential agent in helping cities to face major environmental issues. So, there is a need to integrate urban soil quality into urban planning. We have identified key factors and actions that should be taken to develop a DSS in order to improve the urban planning projects and consequently optimize the ecosystem services provided by urban soils. These are: i) the interdisciplinary work between soil scientists and urban planners; ii) the development of a simple and robust urban soil quality assessment tool, iii) a chain of modules that link urban soil indicators to soil functions, soil covers, ecosystem functions and ecosystem services; (iv) a semi-quantitative assessment of ecosystem services that also integrates economic evaluation, e.g. soil treatment and earthwork savings; (v) a dual "topdown" and "bottom-up" approach that could be implemented at various phases of urban planning. We have proposed the structure of a new DSS dedicated to the redevelopment of urban brownfields by the semiquantitative evaluation of ecosystem services at the scale of a site. DESTISOL is a tangible and a comprehensive tool co-constructed between soil scientists and urban planners. It is based on an integrative approach, linking soil indicators, soil functions, soil covers and soil ecosystem services provided by the various soils of a project site. It is designed to evaluate urban soil potential in terms of ecosystem services in order to guide urban planners in the decision processes required for the sustainable construction of cities. Further development has to be tested in situ on contrasting situations before being used by urban planners and operators. A further step would be to initiate, in addition to this mutual work between soil scientists and urban planners, collaboration with economists, to improve the valuation of ecosystem services.

\section{Acknowledgments}

The authors would like to thank Gérald Fayolle (SCE company), Daniel Rodriguez, Laetitia Boithias and Patrice Morandas (CEREMA), Sarah Ravalet (EPAMSA), Agnès Fraysse and Marie-Cristine Renard (EPF Bretagne) for their conceptual contribution. This work is part of the DESTISOL and SUPRA research projects, which are funded by the 
French Environmental Agency, ADEME. The authors thank the ADEME and the French Grand Est Region for funding the $\mathrm{PhD}$ of Anne Blanchart.

\section{References}

Adhikari, K., \& Hartemink, A. E. (2015). Linking soils to ecosystem services - A global review Geoderma, 262, 101-111.

Andrews, S. S., Karlen, D. L., \& Cambardella, C. A. (2004). The soil management assessment framework. Soil Science Society of America Journal, 68, 1945-1962.

Baveye, P. C., Baveye, J., \& Gowdy, J. (2013). Monetary valuation of ecosystem services: It matters to get the timeline right. Ecological Economics, 95, 231-235 - 10.1016/ j.ecolecon.2013.09.009.

Béchet, B., Carré, F., Florentin, L., Leyval, C., Montanarella, L., Morel, J. L., et al. (2009). Caractéristiques et fonctionnement des sols urbains. In C. Cheverry, \& C. Gascue (Eds.). Sous les Pavés de la Terre (pp. 45-74). Montreuil: Omniscience978-2-91609703-9.

Bolund, P., \& Hunhammar, S. (1999). Ecosystem services in urban areas. Ecological Economics, 29, 293-301.

Burghardt, W., Morel, J. L., \& Zhang, G. L. (2015). Development of the soil research about urban, industrial, traffic, mining and military areas (SUITMA). Soil Science and Plant Nutrition, 3-21.

Cameron, R. W. F., Blanusa, T., Taylor, J. E., Salisbury, A., Halstead, A. J., Henricot, B., et al. (2012). The domestic garden - Its contribution to urban green infrastructure. Urban Forestry \& Urban Greening, 11, 129-137.

Clergeau, P. (2012). Services écologiques et Trame verte urbaine. VertigO - la revue électronique en sciences de l'environnement, hors-série, 12 mai.

Costanza, R., d'Arge, R., deGroot, R., Farber, S., Grasso, M., Hannon, B., et al. (1997). The value of the world's ecosystem services and natural capital. Nature, 253-260.

Craul, P. J. (1992). Urban soil in landscape design. John Wiley \& Sons.

Daily, G. C. (Ed.). (1997). Nature's services. Washington, DC: Island Press.

Davies, Z. G., Edmondson, J. L., Heinemeyer, A., Leake, J. R., \& Gaston, K. J. (2011). Mapping an urban ecosystem service: Quantifying above-ground carbon storage at a city-wide scale. Journal of Applied Ecology, 48, 1125-1134.

de Groot, R. S., Wilson, M. A., \& Boumans, R. M. J. (2002). A typology for the classification, description and valuation of ecosystem functions, goods and services. Ecological Economics, 41, 393-408.

de Kimpe, C. R., \& Morel, J. L. (2000). Urban soil management: A growing concern. Soil Science, 165(1), 31-40.

Dominati, E. (2013). Natural capital and ecosystem services of soils. In J. R. Dymond (Ed.). Ecosystem services in New Zealand - Conditions and trends. Lincoln, New Zealand: Manaaki Whenua Press.

Dominati, E., Patterson, M., \& Mackay, A. (2010). A framework for classifying and quantifying the natural capital and ecosystem services of soils. Ecological Economics, 69, 1858-1868.

Doran, J. W., \& Parkin, T. B. (1994). Defining and assessing soil quality. In J. W. Doran, D. C. Coleman, D. F. Bezdicek, \& B. A. Stewart (Eds.). Defining soil quality for a sustainable environment. Madison, Wisconsin, USA: SSSA Inc.

Effland, W. R., \& Pouyat, R. V. (1997). The genesis, classification, and mapping of soils in urban areas. Urban Ecosystems, 1, 217-228.

El Khalil, H., Schwartz, C., El Hamiani, O., Kubiniok, J., Morel, J. L., \& Boularbah, A. (2008). Contribution of technic materials to the mobile fraction of metals in urban soils in Marrakech (Morocco). Journal of Soils and Sediments, 8, 17-22.

El Khalil, H., Schwartz, C., El Hamiani, O., Kubiniok, J., Morel, J. L., \& Boularbah, A. (2013). Distribution of major elements and trace metals as indicators of technosolisation of urban and suburban soils. Journal of Soils and Sediments, 13(3), 519-530.

ENVASSO. (2006). Environmental Assessment of Soil for mOnitoring. Scientific support to policy - European Commission 6th Framework Programm.

Escobedo, F. J., Kroeger, T., \& Wagner, J. E. (2011). Urban forests and pollution mitigation - Analyzing ecosystem services and disservices. Environmental Pollution, 159, 2078-2087.

Fischer, B., Kerry Turner, R., \& Morling, P. (2009). Defining and classifying ecosystem services for decision making. Ecological Economics, 68, 643-653.

Fondrillon, M. (2007). La formation du sol urbain: étude archéologique des terres noires à Tours (4e-12e siècle). Thèse de doctorat, 539p.

Gaston, K. J., Avila-Jimenez, M. L., \& Edmondson, J. L. (2013). Review - Managing urban ecosystems for goods and services. Journal of Applied Ecology, 50, 830-840.

Georgescu-Roegen, N. (1977). Review - Inequality, limits and growth from a bioeconomic viewpoint. Social Economy, 35(3), 361-375.

Ghiselin, M. T. (Ed.). (1997). Metaphysics and the origin of species. SUNY series in philosophy and biology. Albany: State University of New York Press.

Gómez-Baggethun, E., \& Barton, D. N. (2013). Classifying and valuing ecosystem services for urban planning. Ecological Economics, 86, 235-245.

Hénin, S., Féodoroff, A., Gras, R., \& Monnier, G. (1960). Le profil cultural, principes de physique du sol. Paris: SEIA320.

Hepperle, E., \& Schulin, R. (2008). Soil monitoring and evaluation in the interest of land use planning. Landscape and Urban Planning 88.2-4, 45 pp.

Herrmann, D. L., Shuster. W. D. \& Garmestani, A. S. (2017). Vacant urban lot soils and their potential to support ecosystem services. Plant and soil, 413 (1-2). Springer International Publishing, 45-57.

InVEST. (2015). Integrated valuation of ecosystem services and tradeoffs. Natural capital project.

IUSS Working Group WRB (2015). World reference base for soils resources 2014, update 205. Food and Agriculture Organization of the United Nations.
Jenerette, G. D., Harlan, S. L., Stefanov, W. L., \& Martin, C. A. (2011). Ecosystem services and urban heat riskscape moderation: Water, green spaces, and social inequality in Phoenix, USA. Ecological Applications, 21, 2637-2651.

Jim, C. Y. (1998). Urban soil characteristics and limitations for landscape planting in Hong Kong. Landscape and Urban Planning, 40, 235-249.

Jim, C. Y., \& Chen, W. Y. (2009). Ecosystem services and valuation of urban forests in China. Cities, 26, 187-194.

Joimel, S., Cortet, J., Jolivet, C. C., Saby, N., Chenot, E. D., Branchu, P., et al. (2016). Physico-chemical characteristics of topsoil for contrasted forest, agricultural, urban and industrial land uses in France. Science of the Total Environment, 545-546, 40-47.

Keller, C., \& Robert, S. (2012). Préconisation d'utilisation des sols et qualité des sols en zone urbaine et péri-urbaine - Application du bassin minier de Provence. Programme Gessol. 99 pp.

Kida, K., \& Kawahigashi, M. (2015). Influence of asphalt pavement construction processes on urban soil formation in Tokyo. Soil Science and Plant Nutrition, 61, 135-146.

Leguédois, S., Séré, G., Auclerc, A., Watteau, F., Schwartz, C., Morel, J. -L. (2016). Modeling ecosystem services (es) in soils of urban, industrial, traffic, mining, and military areas (suitmas). In Austin international conference on soil modeling. International Soil Modeling Consortium (ISMC), p. 44

Lehmann, I., Mathey, J., Rossler, S., Brauer, A., \& Goldberg, V. (2014). Urban vegetation structure types as a methodological approach for identifying ecosystem services Application to the analysis of micro-climatic effects. Ecological Indicators, 42, 58-72.

Liu, A. R., Chen, S. C., Lin, X. M., Wu, S. Y., Xu, T., Cai, F. M., et al. (2010). Endophytic Pestalotiopsis species spp. associated with plants of Palmae, Rhizophoraceae, Planchonellae and Podocarpaceae in Hainan, China. Journal of Microbiology, 4, 2661-2669.

Lorenz, K., \& Lal, R. (2009). Biogeochemical C and N cycles in urban soils. Environment International, $35,1-8$.

MEA. (Ed.). (2003). Ecosystem and human well-being - a framework for assessment. Washington DC, Island press.

MEA. (Ed.). (2005). Ecosystems and Human Well-being - Synthesis. Washington DC, Island press.

Morel, J. L., Chenu, C., \& Lorenz, K. (2014). Ecosystem services provided by soils of urban, industrial, traffic, mining, and military areas (SUITMAs). Journal of Soils and Sediments, $1-8$

Morel, J. L., \& Heinrich, A. B. (2008). SUITMA - Soils in urban, industrial, traffic, mining and military areas. Journal of Soils and Sediments, 8(4), 206-207.

Morel, J. L., \& Schwartz, C. (1999). Qualité et gestion des sols de jardins familiaux. Comptes-rendus de L'académie d'Agriculture, 85(2), 103-114.

Morel, J. L., Schwartz, C., \& Florentin, L. (2005). Urban soils. Encyclopedia of Soils in the Environment, 202-208.

Neel, C., Delcour, P., \& Dumont, E. (Ed.). (2012). Les indicateurs de qualités des sols existants sont-ils adaptés aux sols urbains?. PSUR (Préservation des sols en milieu Urbain et Routier) - Centre d'Etudes Techniques de l'Equipement, Ministère de l'Ecologie, du Développement durable et de l'Energie.

Niemelä, J., Saarela, S. R., Söderman, T., Kopperoinen, L., Yli-Pelkonen, V., Väre, S., et al. (2010). Using the ecosystem services approach for better planning and conservation of urban green spaces - A Finland case study. Biodiversity and Conservation, 19, 3225-3243.

Norman, L. M., Villarreal, M. L., Lara-Valencia, F., Yuan, Y. P., Nie, W. M., Wilson, S. et al. (2012). Mapping socio-environmentally vulnerable populations access and exposure to ecosystem services at the U.S.-Mexico borderlands. Applied Geography, $34,413-424$.

Norra, S., \& Stuben, D. (2003). Urban soils. Journal of Soils and Sediments, 3, 230-233.

Oberndorfer, E., Lundholm, J., Bass, B., Coffman, R. R., Doshi, H., Dunnett, N., Gaffin, S., Kohler, M., Liu, K. K. Y., \& Rowe, B. (2007). Green roofs as urban ecosystems: Ecological structures, functions, and services. Bioscience, 57, 823-833.

Ossola, A., \& Livesley, S. J. (2016). Drivers of soil heterogeneity in the urban landscape. In R. A. Francis, (Ed.). Urban landscape ecology: Science, policy and practice. Routledge.

Pouyat, R., Groffman, P., Yesilonis, I., \& Hernandez, L. (2002). Soil carbon pools and fluxes in urban ecosystems. Environment Pollution, 116(Suppl. 1), S107-18.

Pouyat, R., Pataki, D., Belt, K., Groffman, P., Hom, J., \& Band, L. (2007). Effects of urban land-use change on biogeochemical cycles. In J. Canadell, D. Pataki, \& L. Pitelka (Eds.). Terrestrial ecosystems in a changing world: Global change (pp. 45-58). Springer Berlin Heidelberg The IGBP Series.

Pouyat, R., Yesiloni, I., \& Golubiewski, N. (2009). A comparison of soil organic carbon stocks between residential turf grass and native soil. Urban Ecosystems, 12, 45-62.

Pouyat, R., Yesilonis, I. D., \& Nowak, D. J. (2006). Carbon storage by urban soils in the United States. Journal of Environmental Quality, 1566-1575.

Rhea, L., Shuster, W., Shaffer, J., \& Losco, R. (2014). Data proxies for assessment of urban soil suitability to support green infrastructure. Journal of Soil and Water Conservation, $69(3), 254-265$

Robinson (2014). On the value of soil resources in the context of natural capital and ecosystem service deliver. Soil Science Society, 78, 685-700.

Rokia, S., Séré, G., Schwartz, C., Deeb, M., Fournier, F., Nehls, T., et al. (2014). Modelling agronomic properties of Technosols constructed with urban wastes. Waste Management, 34(11), 2155-2162.

Schindelbeck, R. R., van Es, H. M., Abawi, G. S., Wolfe, D. W., Whitlow, T. L., Gugino, B. K., et al. (2008). Comprehensive assessment of soil quality for landscape and urban management. Landscape and Urban Planning, 88, 73-80.

Schmitt-Harsh, M., Mincey, S. K., Patterson, M., Fischer, B. C., \& Evans, T. P. (2013). Private residential urban forest structure and carbon storage in a moderate-sized urban area in the Midwest, United States. Urban Forestry \& Urban Greening, 12, 454-463.

Schwartz, C. (2001). Measurement of in situ phytoextraction of zinc by spontaneous metallophytes growing on a former smelter site. Science of the Total Environment, 
279(1-3), 215-221.

Séré, G., Schwartz, C., Ouvrard, S., Sauvage, C., Renat, J. C., \& Morel, J. L. (2008). Soil construction: A step for ecological reclamation of derelict lands. Journal of Soils and Sediments, 8, 130-136 - 10.1065/jss2008.03.277.

Shaw, R. (2015). Soils in urban areas - Characterization, management, challenges. Soil Science, 180 ISSN: 1538-9243.

Taylor, N. (2007). Urban planning theory since 1945. London: Sage.

TEEB. (2011). Manual for cities: Ecosystem Services in Urban Management, in A.

Berghöfer, ed., James Blignaut, Martin de Wit, Hugo van Zyl.

UFORE. (2009). Urban forest effects model. United States Department of Agriculture.

UQUALISOL-ZU. (2012). Préconisation d'utilisation des sols et qualité des sols en zone urbaine et péri-urbaine - Application du Bassin Minieur de Provence. Programme
ADEME - GESSOL.

Urban SMS. (2008). Bodenmanagement-Stategie für städtische Räume. INTERREG IV B der Europäischen Union Programm. Zentraleuropäischer Kooperationsraum (Central Europe).

Velasquez, E., Lavelle, P., \& Andrade, M. (2007). GISQ, a multifunctional indicator of soi quality. Soil Biology \& Biochemistry, 39, 3066-3080.

Vrščaj, B., Poggio, L., \& Marsan, F. A. (2008). A method for soil environmental quality evaluation for management and planning in urban areas. Landscape and Urban Planning, 88, 81-94.

Williams, A., \& Hedlund, K. (2014). Indicators and trade-offs of ecosystem services in agricultural soils along a landscape heterogeneity gradient. Applied Soil Ecology, 77, 1-8 